UCRL-ID-119535

\title{
Progress Reports for October 1994 - Joint UK/US Radar Program
}

\author{
R. E. Twogood \\ J. M. Brase \\ D. D. Mantrom \\ D. H. Chambers \\ H. F. Robey
}

November 18, 1994

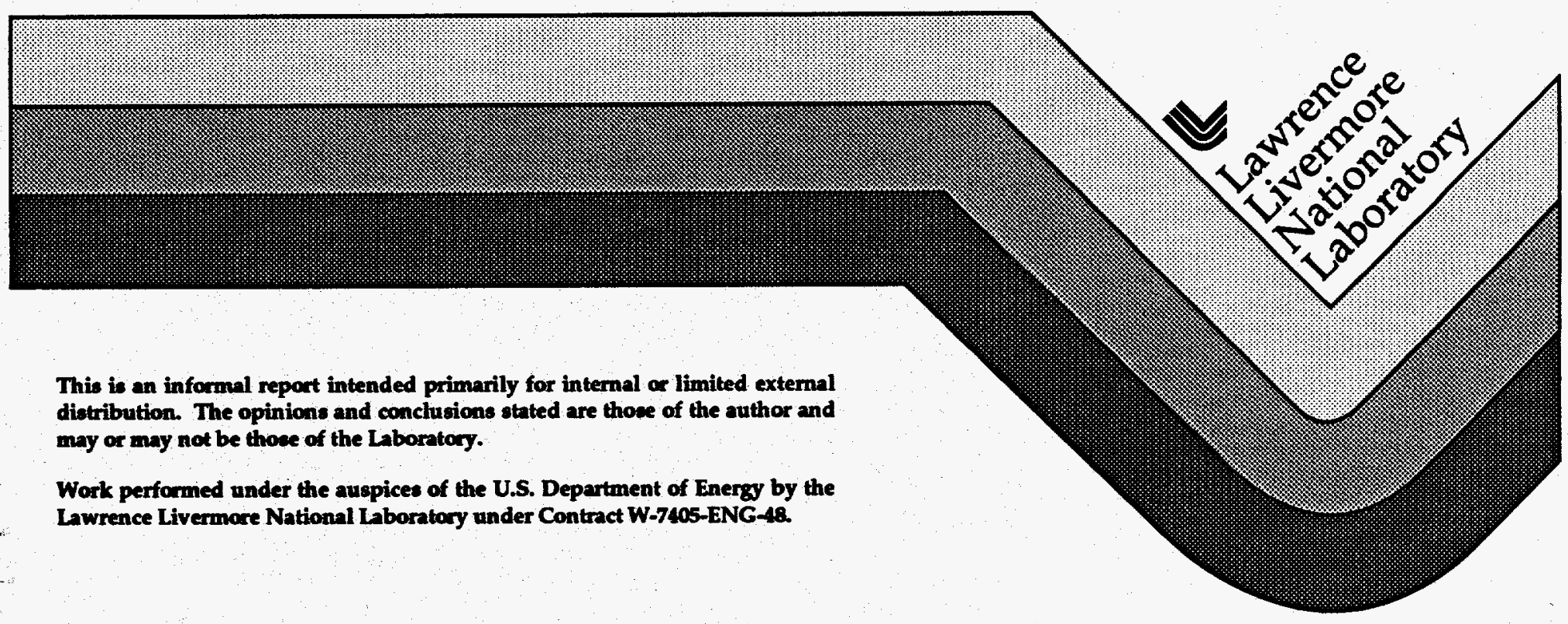

$-1 \mathrm{CH}$

JII! 251995 


\section{DISCLAMMER}

This document was prepared as an scoount of work sponsored by an agency of the United States Government. Neither the United States Government nor the University of California nor any of their employees, makes any warranty, express or implied, or assumes any legal liability or responsibility for the accuracy, completeness, or usefulness of any information, apparntus, product, or process disclosed, or represents that its use would not infringe privately owned rights. Reference herein to any specific commerdal product, process, or service by trade name, trademark, mmufacturer, or otherwise, does not necessarily constitute or imply its endorsement, recommendation, or favoring by the United States Covernment or the University of California. The views and opinions of authors expressed herein do not necesearily state or reflect those of the United States Government or the University of California, and shall not be used for advertising or product endorsement purposes.

This report has been reproduced directly from the best available copy.

\section{Available to DOE and DOE contractors from the \\ Office of Scientific and Technical Information \\ P.O. Box 62, Oak Ridge, TN 37831}

Prices available from (615) 576-8401, FTS 626-8401

Avallable to the public from the

National Technical Information Service

U.S. Depertment of Commerce

5285 Port Royal Rd.

Springfield, VA 22161 


\section{DISCLAIMER}

Portions of this document may be illegible in electronic image products. Images are produced from the best available original document. 
Organization: LLNL

Program: P.LLN.1010 Airborne RAR/SAR

Principal Investigator: Richard E. Twogood

Current Objectives:

Modify Hughes $\mathrm{x}$-band radar for airborne implementation.

Upgrade to polarimetry, high-power, and add SLAR mode.

Deploy in UK/US field experiments as needed.

Recent accomplishments:

Work continued on hardware procurements, system integration, and software development for the LLNL-led tasks. Hughes Aircraft stopped work on the radar design and associated control hardware/software due to lack of fund; they decided to not run at risk and are awaiting additional funds. They plan to restart by Dec. 1 pending receipt of funding from LLNL (which is forthcoming from the additional FY94 funds MIPRed to LLNL by ISSO on 10/25/94).

The overall radar and testbed is now scheduled for engineering checkout in April 1995, pending the arrival of FY95 funds as expected (12/94).

Milestones for the reporting period:

Ongoing design work continued; no major milestones scheduled for October.

Expected milestones for the ensuing period:

March 1995 Engineering Checkout(s)

June 1995 First experimental deployment

\section{Other Issues:}

There has been a few week slip due to the absence of funds on 10/1/94; Hughes has moved some of the radar work back until the next increment of funding is available (FY94 funds sent out by ISSO on 10/25).

\section{Planned expenditures versus actuals:}

FY95 Budget Plan: $\quad \$ 1500 \mathrm{~K}$

October 94 costs: $\quad \$ 65 \mathrm{~K}$

Year-to-date costs: $\quad \$ 65 \mathrm{~K}$ 


\section{Organization: LLNL}

\section{Program: P.LLN.1020 Radar Data Processor}

Principal Investigator: James M. Brase

\section{Current Objectives:}

Integration and test of the real-time SAR processor for the Hughes airborne radar; define and develop the SAR Doppler and related analysis software for this unique system; develop the similar system for the UK testbed (OITB)

\section{Recent accomplishments:}

The radar data processor computer hardware has all been successfully integrated. Test programs were also successfully run on the Mercury parallel processor. Work continued on the baseline SAR processing software system.

\section{Milestones for the reporting period:}

All major hardware systems successfully integrated and checked out.

Expected milestones for the ensuing period:

Preliminary design review with the UK (Keith Ward) during December 1994. Baseline SAR processor software to be completed by early December.

\section{Other Issues:}

None.

Planned expenditures versus actuals:

FY95 Budget Plan: \$750K

October 94 costs: $\quad \$ 110 \mathrm{~K}$

Year-to-date costs: $\quad$ \$110K 
Organization:

LLNL

Program: P.LLN.1030 Ground-based SAR Signal Processing Workstation

Principal Investigator: James M. Brase

Current Objectives:

Develop capabilities for motion compensation and autofocus for Hughes SAR and UK system. Enhance SAR processors with multi-look software. Analyze the low-grazing angle (LGA) processing steps and improve performance of LGA processing.

Recent accomplishments:

LGA Doppler processing software was successfully completed and checked out. Roger Manasse documented suggestions on software modifications that would result in significant computational savings and potential detection improvements. Work has begun on implementing those suggested changes, and a speed-up of a factor of two is expected.

Milestones for the reporting period:

LGA Doppler processing software completed.

Expected milestones for the ensuing period:

Manasse modifications to be implemented by December 1994.

Full motion compensation software for Hughes airborne system by March 95 . Autofocus upgrade to processor by April 1995.

\section{Other Issues:}

None.

Planned expenditures versus actuals:

FY95 Budget Plan:

October 94 costs:

$\$ 750 \mathrm{~K}$

Year-to-date costs:

$\$ 40 \mathrm{~K}$

$\$ 40 \mathrm{~K}$ 
Organization: LLNL

Program: P.LLN.1040 Static Airborne Radar

Principal Investigator: Richard E. Twogood

Current Objectives:

Procure GFE excess equipment including aerostats, platforms, and ancillary systems. Perform checkout of hardware. Assess options for stabilized realaperture radar experiments using these aerostats systems. FY95 funding permitting, include these systems in radar experiments beginning in summer 1995.

\section{Recent accomplishments:}

Further preliminary checkout of the mooring platforms that have arrived at LLNL was performed - they appear to be in very good shape, although current thinking is that the Atlantic Sentry platform will not be particularly useful but can be used for spare parts. This leaves one full system at LLNL, plus one at still at New Orleans for future Autec or east coast use. It should be noted here that LLNL has also obtained another mooring platform that was excess GFE from Beaumont, Texas, and DoE funds are available for integration of that hardware. That system appears very well suited for turning into the truck- or ship-mounted, transportable system and we are investigating what it will require to make that system usable for the UK/US experiments.

Milestones for the reporting period:

Initial checkout of OSD-procured mooring platforms, APS 143 radars, and support systems begun.

Expected milestones for the ensuing period:

Conceptual design for aerostat radar system deployment options with cost estimates to be completed by November 1994.

Down-select from options once FY95 funding received (December 1994).

Initial radar system checkout and experiments, June 1995.

\section{Other Issues:}

We are still anticipating being able to support a field test by late summer, but long-lead procurements need to begin soon (Dec. 1 was our plan). Those procurements are ready but must await receipt of the first FY95 funding (expected by early to mid-December). Recent feedback from the UK indicates they will not be prepared to do simultaneous helicopter-based static radar tests during FY95, but that does not significantly impact our plans (indeed, in some respects it increases the priority of this task).

Planned expenditures versus actuals:

FY95 Budget Plan: $\quad \$ 1000 \mathrm{~K}$ 
October 94 costs:

Year-to-date costs:
$\$ 80 \mathrm{~K}$

$\$ 80 \mathrm{~K}$ 
Organization: LLNL

Program: P.LLN.1050 Multi-Aperture Space-Time Array Radar

Principal Investigator: James M. Brase

Current Objectives:

Perform feasibility study and preliminary design of a multi-aperture radar for high resolution, in both range and azimuth, imaging of the ocean surface.

\section{Recent accomplishments:}

None -- project starts upon receiving FY95 funds.

\section{Milestones for the reporting period:}

None - project not yet started.

Expected milestones for the ensuing period:

Initiation of project circa December 1994; preliminary discussion of system options with Keith Ward by December.

\section{Other Issues:}

None.

Planned expenditures versus actuals:

FY95 Budget Plan: \$200K

October 94 costs: $\quad \$ 0 \mathrm{~K}$

Year-to-date costs: $\quad \$ 0 \mathrm{~K}$ 
Organization: LLNL

Program: P.LLN.1060 Radar Field Experiments

Principal Investigator: David Mantrom

Current Objectives:

Complete analysis of Loch Linnhe 1994 data. Plan and prepare for 1995 trials, including static airborne system test(s), and a potential detection test in summer or early autumn 1995.

Recent accomplishments:

Draft reports on the Loch Linnhe 1994 experiment summarizing test operations, on-site data analysis, and in-water profile data have been completed. Distribution of these reports will occur in November. Detailed analysis of LL94 data is continuing, including kinematic analysis based on density and shear profile data. Preliminary planning for FY95 field experiments has begun, with possibilities including Autec and/or the Columbia River test in collaboration with ETL. Environmental data have been obtained and analyzed to support site and test period evaluation.

Milestones for the reporting period:

Preliminary reports on LL94 experiment written.

Expected milestones for the ensuing period:

Completion of quick look reports from Loch Linnhe 94 experiment Nov. 1994. Determination of 1995 experiment plans upon meeting with UK researchers Nov. 28 - Dec. 2, 1994.

Initial field experiment reports and community-wide meetings by Feb. 1995.

Other Issues:

None.

Planned expenditures versus actuals:

FY95 Budget Plan: $\quad \$ 2000 \mathrm{~K}$

October 94 costs: $\quad \$ 109.5 \mathrm{~K}$

Year-to-date costs: $\quad \$ 109.5 \mathrm{~K}$ 
Organization: LLNL

Program: P.LLN.1070 Data Analysis and Detection Theory

Principal Investigator: James M. Brase

\section{Current Objectives:}

Complete baseline analysis of Loch Linnhe data.

Complete report on MTF for LGA data (1989-94 data sets).

Continue Doppler analysis and detection implications.

Analysis of UCSB data as it comes in.

\section{Recent accomplishments:}

Met at LLNL (with Keith Ward) to review Loch Linnhe 1994 quick-look results : A priority list for further analysis was established. We decided that LLNL would have primary responsibility for radar data analysis from LL94, enabling DRA Malvern to focus on data analysis from other UK-only tests recently performed. Problems with the Thorn EMI radar hardware during the experiment were discussed. Imbalance in the quadrature mixer and periodic digitizer noise limit the clutter-to-noise ratio to $8-10 \mathrm{~dB}$ rather than the expected 20-30 dB. Kinematic and modulation analysis should not be impacted by this, but Doppler analysis may be less effective than hoped. Detailed Doppler analysis of the priority runs is underway to determine the full implications - initial assessmentss should be complete by end of November.

Draft report on Doppler dependence of internal wave wake modulation was completed. Currently responding to comments by $\mathrm{R}$. Manasse; should be completed by late November.

Milestones for the reporting period:

Loch Linnhe quick-look data analysis and all transcription completed 9/94.

Expected milestones for the ensuing period:

Doppler analysis report complete 11/94.

Baseline analysis reports for Loch Linnhe 94 complete 11/94.

Ship wake meeting 11/94 at LLNL.

\section{Other Issues:}

None.

Planned expenditures versus actuals:

FY95 Budget Plan: \$700K

October 94 costs: $\quad \$ 115 \mathrm{~K}$

Year-to-date costs: $\quad \$ 115 \mathrm{~K}$ 
Organization: LLNL

\section{Program: P.LLN.1080 Management}

Principal Investigator: Richard E. Twogood

\section{Current Objectives:}

Provide ongoing management oversight and support for the Joint UK/US Radar Program (Twogood) and staff support in Washington for the ASAP program office (Thomson, Hutchins, Chocol), in addition to other consultant and management services (Wells, Manasse, etc.).

\section{Recent accomplishments:}

Coordination of future meetings and new initiatives was performed. Preparations for Ship Wake meeting at LLNL (11/29-30) and Scientific Coordination Working Group (12/1). Robey and Mantrom attended ETL 2day meeting. Continued full-time support of ISSO Ballston office by Thomson, Hutchins, and Chocol. Manasse continued providing technical advice for LGA work.

\section{Milestones for the reporting period:}

ASAP Work Unit Assignment package completed by Washington-based program staff. This certainly has brought a well-documented and clear structure to the tasks and deliverables in the UK/US program, and LLNL and the other contractors have had no apparent difficulty in transitioning to that structure with a minimum of effort.

Expected milestones for the ensuing period:

Ongoing support to ISSO office by program office staff. Ship Wake meeting and Scientific Coordination Working Group meeting at LLNL.

\section{Other Issues:}

None.

Planned expenditures versus actuals:

FY95 Budget Plan: $\quad \$ 1000 \mathrm{~K}$

October 94 costs: $\quad \$ 149 \mathrm{~K}$

Year-to-date costs: $\quad \$ 149 \mathrm{~K}$ 
Organization: LLNL

Program: P.LLN.1090 E-2C Radar Data Analysis

Principal Investigator: Charles Rino

Inputs to be provided separately to ISSO directly by Vista Research. 
Organization: LLNL

Program: P.LLN.1110 Modeling and Analysis (LLNL)

Principal Investigator: David Chambers

Current Objectives:

Analysis of Loch Linnhe 1994 hydrodynamics data.

Recent accomplishments:

Reworked 2D+T wake initialization to obtain consistency with RDA code.

Initial analysis of profile datga from Loch Linnhe 1994 completed by Harry

Robey. Continued development of turbulent wake source models for

internal waves to assist interpretation of IAP data and evaluate application to Loch Linnhe 1994 data.

Milestones for the reporting period:

Consistency obtained between 2D+T code and RDA code.

Expected milestones for the ensuing period:

Documentation of hydro analysis for Loch Linnhe by December 1994.

Complete turbulent wake source model and comparison with IAP wave tank data.

Other Issues:

None.

Planned expenditures versus actuals:

FY95 Budget Plan: \$330K

October 94 costs: $\quad \$ 14.9 \mathrm{~K}$

Year-to-date costs: $\quad \$ 14.9 \mathrm{~K}$ 


\section{Organization: LLNL}

Program: P.LLN.1150 Modeling and Analysis (Vista)

Inputs to be provided to ISSO directly by Vista Research. 
Organization: LLNL

Program: P.LLN.1170 Current Meter Array

Principal Investigator: David Mantrom

Current Objectives:

Loch Linnhe 1994 CMA data analysis and documentation.

Upgrades to power system, structure, and data acquisition for future tests.

\section{Recent accomplishments:}

Analysis of the CMA data from Loch Linnhe has continued. Emphasis has been placed on sensor performance characterization and generating statistics of the current meter data to form the basis of noise rejection algorithms which will subsequently be applied to the ship wake data. We have also written a paper that has been submitted and accepted for presentation at the IEEE Fifth Working Conference on Current Measurement in St. Petersburg, FL in February 1995.

Milestones for the reporting period:

Successful deployment of CMA and related systems at Loch Linnhe 1994.

Expected milestones for the ensuing period:

Initial reports on CMA data, analysis, and interpretation by November 1994.

Other Issues:

None.

Planned expenditures versus actuals:

FY95 Budget Plan: \$300K

October 94 costs: $\quad \$ 10 \mathrm{~K}$

Year-to-date costs: $\quad \$ 10 \mathrm{~K}$ 
Organization: LLNL

Program: P.LLN.1410 UCSB Wave Tank

Principal Investigator: Harry Robey

Current Objectives:

Continue hydro measurements program at UCSB.

Install radars in tank: initially UCSB's C-band and LLNL's existing wideband;

later TRW's $x$-band.

Recent accomplishments:

Significant progress has been made on the radar systems to be deployed at the UCSB tank. A meeting was held at UCSB to review the status. The UCSB linear FM radar $(5-8 \mathrm{Ghz})$ is operating and undergoing initial engineering tests. The LLNL impulse radar (1-3 Ghz) is operational. The TRW radar (10 Ghz) is expected to be ready in January 1995.

The impulse radar has made measurements of backscatter from breaking waves with an apparent $\mathrm{VV} / \mathrm{HH}$ ratio of $20 \mathrm{~dB}$.

Milestones for the reporting period:

Successful checkout of LLNL wideband radar at UCSB and UCSB radar.

Expected milestones for the ensuing period:

Installation of UCSB C-band system 12/94.

Installation of LLNL wideband system (on more or less permanent basis)

12/94. Begin calibration procedures. Synchronize with UCSB video system.

\section{Other Issues:}

None.

Planned expenditures versus actuals:

FY95 Budget Plan: $\quad \$ 800 \mathrm{~K}$

October 94 costs: $\quad \$ 65.3 \mathrm{~K}$

Year-to-date costs: $\quad \$ 65.3 \mathrm{~K}$ 
Organization: LLNL

Program: P.LLN.1420 Stratified Flow Facility

Principal Investigator: Harry Robey

Current Objectives:

Re-start internal wave measurements program with emphasis on turbulence generated IW phenomena.

Recent accomplishments:

Design of the extension of the test section is finished; preparations for the test section enlargement in early FY95 are underway.

Milestones for the reporting period:

None.

Expected milestones for the ensuing period:

Extension of test section and system checkout by April 1995.

Other Issues:

None.

Planned expenditures versus actuals:

FY95 Budget Plan:

October 94 costs:

$\$ 200 \mathrm{~K}$

Year-to-date costs:

$\$ 11 \mathrm{~K}$

$\$ 11 \mathrm{~K}$ 
Organization: LLNL

Program: P.LLN.1430 Institute of Applied Physics, Russia

Principal Investigator: Harry Robey

\section{Current Objectives:}

Conduct wave tank studies at IAP in Russia; current emphasis on extension of previous results to turbulence generated wave effects and study of current shear effects.

\section{Recent accomplishments:}

Contract preparations for the next phase of the tank work at the Institute for Applied Physics in Nizhny Novgorod, Russia, were completed. A primary thrust of the work will be to extend the studies previously completed under the last phase of work (mainly turbulence generated internal wave studies) and addition of shear flow in the tank. The contract should be placed with IAP in the November 1994 time frame, although further delays may occur if FY95 funding arrives late.

Milestones for the reporting period:

None.

Expected milestones for the ensuing period:

Contract placement in November 94.

\section{Other Issues:}

None.

Planned expenditures versus actuals:

FY95 Budget Plan: $\quad \$ 350 \mathrm{~K}$

October 94 costs: $\quad \$ 0 \mathrm{~K}$

Year-to-date costs: $\quad \$ 0 \mathrm{~K}$ 
Organization: LLNL

Program: P.LLN.1210 IR Sensor Systems

Principal Investigator: Jerry Belyea

Inputs to be provided to ISSO directly by ERIM. 


\section{Budget Status}

Budget breakdown by individual ISSO work assignment are described in the above individual work unit assignments. Overall UK/US Radar Program funding status is as follows:

October 94 costs:

Year-to-date costs:

Ledger liens:

Pre-liens:

Non-ledger liens:

Funds remaining:

\author{
$\$ 837.0 \mathrm{~K}$ \\ $\$ 837.0 \mathrm{~K}$ \\ $\$ 1666.7 \mathrm{~K}$ \\ $\$ 140.1 \mathrm{~K}$
}

\$1200.0K (estim.) (unaccrued costs on liens and preliens plus at-risk funding by contractors)

- \$2005.4 (overrun as of 11/1/94)

Discussion of funding: ISSO MIPRed $\$ 3.0 \mathrm{M}$ on 10/25/94 to address this overrun. Upon receipt by LLNL of those funds, the above overrun will be corrected and the at-risk funds paid off (most not yet even invoiced to LLNL yet).

This work was performed under the auspices of the Department of Energy by the Lawrence Livermore National Laboratory under contract W-7405-Eng-48. 